\title{
STRATEGI PENGEMBANGAN AGROINDUSTRI KERIPIK UBI KAYU (Studi Kasus pada Perusahaan Jaya Sari di Desa Selamanik Kecamatan Cipaku Kabupaten Ciamis)
}

\author{
Oleh : \\ IDA MAESAROH \\ FAKULTAS PERTANIAN UNIVERSITAS GALUH CIAMIS \\ e-mail:ghaizanialkasindar@gmail.com \\ SAEPUL AZIZ \\ FAKULTAS PERTANIAN UNIVERSITAS GALUH CIAMIS \\ e-mail:alaziz9933@gmail.com
}

\begin{abstract}
Abstrak
Penelitian ini bertujuan untuk mengetahui (1) Besarnya biaya, penerimaan dan pendapatan, (2) Faktor internal dan eksternal yang berpengaruh terhadap pengembangan agroindustri keripik ubi kayu, (3) Alternatif strategi yang dapat diterapkan dalam pengembangan agroindustri keripik ubi kayu di Desa Selamanik Kecamatan Cipaku Kabupaten Ciamis.

Jenis penelitian yang digunakan dalam penelitian ini adalah metode studi kasus. Data yang dikumpulkan meliputi data primer dan data sekunder. Penarikan responden dalam penelitian ini dilakukan purposive sampling yaitu penetuan sampel dengan pertimbangan tertentu yang dipandang dapat memberikan data secara maksimal, maka responden yang diambil satu orang pengusaha keripik ubi kayu di Desa Selamanik Kecamtan Cipaku Kabupaten Ciamis.

Hasil penelitian menunjukan bahwa:

1) Besarnya biaya total yang dikeluarkan oleh pengusaha keripik ubi kayu dalam satu kali proses produksi sebesar $\mathrm{Rp} 1.152 .500,00$ penerimaannya sebesar $\mathrm{Rp} 2.850 .000,00$ dan pendapatannya sebesar Rp 1.697.500,00.

2) Faktor internal dan eksternal yang berpengaruh pada pengembangan agroindustri keripik ubi kayu di Desa Selamanik Kecamatan Cipaku Kabupaten Ciamis terdiri dari kekuatan, kelemahan dan peluang, ancaman. Faktor-faktor yang menjadi kekuatan yaitu tersedianya cukup jumlah tenaga kerja, produksi mudah dilakukan, produk keripik ubi kayu yang tahan lama, harga produk yang terjangkau. Sedangkan faktor-faktor yang menjadi kelemahan yaitu keterbatasan permodalan, kualitas SDM yang masih kurang, pengemasan produk masih sederhana, dan promosi masih kurang. Faktor-faktor yang menjadi peluang yaitu tidak ada pesaing produk sejenis disatu daerah, pangsa pasar yang masih luas, permintaan semakin meningkat, cuaca tidak mempengaruhi produksi. Faktor-faktor yang menjadi ancaman yaitu kelangkaan bahan baku, fluktuasi harga bahan baku, kurang adanya peran dari pemerintah, dan kenaikan harga sarana produksi.

3) Alternatif strategi yang dapat diterapkan dalam pengembangan agroindustri keripik ubi kayu di Desa Selamanik Kecamatan Cipaku Kabupaten Ciamis yaitu mempertahankan kualitas produksi dan pengembangan pasar, mempertahankan kontinyuitas produksi untuk memenuhi permintaan, optimalisasi kualitas SDM untuk memenuhi permintaan produk, diversifikasi produk untuk memenuhi pangsa pasar, pengelolaan tenaga kerja dan ketersediaan bahan baku, keseragaman harga jual dengan peran serta pengawasan pemerintah, penganekaragaman pengemasan untuk memaksimalkan produksi dan menjalin kerja sama dengan pihak terkait dalam menyikapi permodalan.
\end{abstract}

Kata kunci : Strategi, Agroindustri, Kripik ubi kayu 


\section{A MIMBAR AgRIBISNIS \\ ISSN 2460-4321}

Volume 1 - Nomor 3 Juli 2016

\section{PENDAHULUAN}

Selama ini kontribusi sektor pertanian terhadap penerimaan devisa lebih banyak diperoleh dari produk segar (primer) yang relatif memberi nilai tambah kecil dan belum mengandalkan produk olahan (hilir) yang dapat memberikan nilai tambah lebih besar, walaupun pada akhir-akhir ini ekspor produk olahan telah semakin besar. Dengan mengekspor produk primer, maka nilai tambah yang besar akan berada di luar negeri, padahal sebaliknya bila Indonesia mampu mengekspor produk olahannya, maka nilai tambah terbesarnya akan berada di dalam negeri (Azhari, 2004).

Produk agroindustri yang memiliki daya tarik akan bahan bakunya, proses produksinya, bentuk produknya dan permintaannya adalah agroindustri dengan bahan baku buah ubi kayu. Ubi kayu mudah tumbuh dengan subur di sebagian besar wilayah. Berbagai jenis ubi kayu tumbuh dan menjadi tanaman yang cukup mudah ditemui.

Keripik ubi kayu merupakan produk yang banyak terdapat di Kabupaten Ciamis. Hal tersebut didukung oleh lahan yang potensial untuk budidaya tanaman ubi kayu, selain itu ubi kayu juga dapat tumbuh di berbagai tempat. Disamping harga keripik ubi kayu yang kompetitif dibandingkan dengan produk lain, membuat pangsa pasar produk ini masih luas.

Di Kecamatan Cipaku terdapat beberapa agroindustri keripik ubi kayu, namun agroindustri keripik ubi kayu milik perusahaan Jaya Sari merupakan agroindustry dengan volume jual terbanyak dibanding dengan agroindustri kripik ubi kayu lainnya yaitu sebanyak 5.700 pcs per satukali produksi yang dipasarkan ke beberapa wilayah di kecamatan Cipaku dan Kota Cirebon.

\section{TINJAUAN PUSTAKA}

Analisis SWOT adalah identifikasi berbagai factor secara sistematis untuk merumuskan strategi perusahaan. Analisis ini didasarkan pada logika yang dapat memaksimalkan kekuatan (Strenghts) dan peluang (Opportunities), namun secara bersamaan dapat meminimalknan kelemahan (Weaknesses) dan ancaman (Thereats). Proses pengambilan keputusan strategis selalu berkaitan dengan pengembangan misi, tujuan, dan kebijakan perusahaan.

\section{METODE PENELITIAN}

Jenis penelitian yang digunakan dalam penelitian ini adalah metode studi kasus, dengan mengambil kasus pada pengusaha keripik ubi kayu di Desa Selamanik Kecamatan Cipaku Kabupaten Ciamis. Menurut Nazir (2011), studi kasus merupakan suatu penelitian yang bersifat mendalam mengenai suatu karakteristik tertentu dari objek penelitian. (Rangkuti, 2009)

Data yang dikumpulkan meliputi data primer dan data sekunder. Data primer ialah data yang diperoleh secara langsung dari pengusaha keripik ubi kayu yang dijadikan responden melalui wawancara, sedangkan data sekunder adalah data yang diperoleh dari literatur-literatur dan data dari instansi atau dinas terkait yang ada hubungannya dengan penelitian ini.

Menurut Arikunto (2006) purposive sampling yaitu penetuan sampel dengan pertimbangan tertentu yang dipandang dapat memberikan data secara maksimal. Berdasarkan pengertian tersebut maka pada penelitian ini ditentukan seorang pengusaha keripik ubi kayu pada perusahaan Jaya Sari yang ada di Desa Selamanik Kecamatan Cipaku Kabupaten Ciamis, karena agroindustri keripik ubi kayu tersebut merupakan agroindutri dengan volume jual tertinggi disbanding agroindutri lainnya. Selain itu sebagai responden pendukung yaitu satu orang Pemerintah Desa Selamanik dan satu orang dari Dinas Pertanian sebagai orang yang terlibat aktif dalam kegiatan yang menjadi perhatian peneliti dan sebagai pemegang kebijakan.

\section{1) Analisis Usaha}

a. Menghitung Biaya

$\mathrm{TC}=\mathrm{TFC}+\mathrm{TVC}$

dimana :

$\mathrm{TC}=$ Total cost (biaya total)

$\mathrm{TFC}=$ Total fixed cost (biaya tetap total)

$\mathrm{TVC}=$ Total variable cost (biaya variabel total)

\section{b. Menghitung Penerimaan}

TR $=$ Hy . Y

dimana 


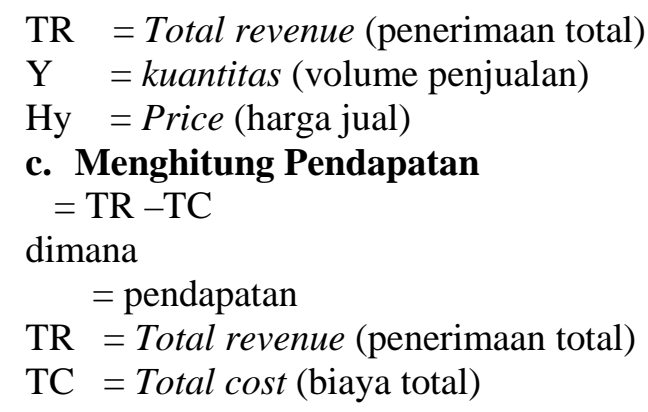

\section{2). Analisis Faktor Eksternal dan Faktor Internal}

Analisis faktor internal bertujuan untuk mengidentifikasi faktor-faktor internal kunci yang menjadi kekuatan dan kelemahan di dalam pengembangan agroindustri keripik ubi kayu. Faktor internal yang dianalisis meliputi produksi, sumber daya manusia, manajemen, keuangan dan pemasaran. Analisis faktor eksternal bertujuan untuk mengidentifikasi faktor-faktor eksternal kunci yang menjadi peluang dan ancaman bagi pengembangan agroindustri keripik ubi kayu. Faktor eksternal yang dianalisis meliputi kondisi perekonomian, pemerintah, sosial budaya, teknologi, pemasok dan konsumen serta pesaing.

Untuk mengidentifikasi kekuatan dan kelemahan dari faktor internal serta peluang dan ancaman dari faktor eksternal dalam mengembangkan agroindustri keripik ubi kayu di Desa Selamanik Kecamatan Cipaku Kabupaten Ciamis digunakan analisis SWOT. Analisis SWOT adalah identifikasi berbagai faktor secara sistematis untuk merumuskan strategi pengembangan agroindustri keripik ubi kayu. Analisis ini didasarkan pada logika yang dapat memaksimalkan kekuatan (strengths) dan peluang (opportunities), namun secara bersamaan dapat meminimalkan kelemahan (weaknesses) dan ancaman (threats).

\section{3). Alternatif Strategi}

Untuk merumuskan alternatif strategi pengembangan agroindustri keripik ubi kayu di Desa Selamanik Kecamatan Cipaku Kabupaten Ciamis digunakan analisis Matriks SWOT. Analisis SWOT digambarkan ke dalam Matriks SWOT dengan 4 kemungkinan alternatif strategi, yaitu stategi kekuatan-peluang ( $S$ - $O$ strategies), strategi kelemahan-peluang ( $\mathrm{W}-\mathrm{O}$ strategies), strategi kekuatan-ancaman (S-T strategies), dan strategi kelemahan-ancaman (W-T strategies).

Penelitian ini dilaksanakan pada seorang perajin agroindustri keripik ubi kayu di Desa Selamanik Kecamatan Cipaku Kabupaten Ciamis sejak bulan April sampai bulan Juni 2016

\section{HASIL DAN PEMBAHASAN}

\section{A. Identitas Responden}

Responden dalam penelitian ini terdiri dari pengusaha keripik ubi kayu, Pemerintah Desa Selamanik dan Dinas Pertanian. Identitas responden meliputi umur, tingkat pendidikan, tanggungan keluarga dan pengalaman berusaha. Selengkapnya mengenai identitas responden dibahas sebagai berikut :

\section{Umur Responden}

Umur merupakan salah satu faktor yang dapat mempengaruhi kemampuan seseorang dalam bekerja. Sebagian besar responden masih tergolong ke dalam usia produktif, yaitu usia 45-50 tahun sehingga mempunyai tingkat kemampuan yang memungkinkan untuk menjalankan usahanya.

\section{Pendidikan Responden}

Lama pendidikan formal responden yaitu 9 tahun atau setingkat dengan lulusan Sekolah Lanjutan Tingkat Pertama (SLTP). Responden mampu melaksanakan wajib belajar 9 tahun sehingga diperkirakan terhindar dari permasalahan buta huruf.

\section{Jumlah Tanggungan Keluarga Responden}

Tanggungan keluarga yang dimaksud dalam penelitian ini adalah banyaknya jumlah anggota keluarga yang menjadi tanggunan responden untuk memenuhi kebutuhan hidupnya. Pada umumnya responden memiliki tanggungan keluarga sebanyak $3-4$ orang.

\section{Pengalaman Berusaha Responden \\ Pengalaman responden dalam} mengusahakan agroindustri keripik ubi kayu yaitu 23 tahun. Bisa diketahui bahwa responden sudah sangat berpengalaman dalam 


\section{AIMBAR AgRIBISNIS \\ ISSN 2460-432.}

Volume 1 Nomor 3 Juli 2016

menjalankan usahanya. Pengalaman berusaha akan mempengaruhi dalam menjalankan usahanya seperti menyikapi permasalahan dan mengambil keputusan dalam proses produksi keripik ubi kayu.

\section{B. Analisis Usaha}

Biaya yang dihitung dalam proses produksi keripik ubi kayu selama satu kali proses produksi terdiri dari biaya tetap dan biaya variabel. Biaya tetap meliputi biaya Pajak Bumi dan Bangunan (PBB), biaya penyusutan alat dan bunga modal. Sedangkan Biaya variabel yang dikeluarkan oleh perajin keripik ubi kayu terdiri dari biaya sarana produksi, upah tenaga kerja dan transportasi.

Untuk lebih jelasnya mengenai analisis usaha dapat dilihat pada Tabel 1

Tabel 1. Hasil Produksi, Penerimaan dan Pendapatan pada Agroindustri Keripik Ubi kayu di Desa Selamanik dalam Satu Kali Proses Produksi

\begin{tabular}{|c|l|c|r|}
\hline No & \multicolumn{1}{|c|}{ Uraian } & Satuan & \multicolumn{1}{|c|}{ Nilai } \\
\hline 1. & Hasil produksi & Pcs & 5.700 \\
\hline 2. & Harga jual keripik ubi kayu & Rp./Pcs & 500,00 \\
\hline 3. & Penerimaan & Rp. & $2.850 .000,00$ \\
\hline 5. & Biaya tetap & Rp. & $16.540,00$ \\
\hline 6. & Biaya variabel & Rp. & $1.134 .066,00$ \\
\hline 7 & Bunga Modal tetap & Rp. & $1.894,00$ \\
\hline 8. & Biaya total & Rp. & $1.152 .500,00$ \\
\hline 9. & Pendapatan & Rp. & $1.697 .500,00$ \\
\hline & & & \\
\hline
\end{tabular}

\section{Identifikasi Faktor Internal dan Eksternal \\ 1. Faktor Internal}

Faktor internal merupakan faktor yang berasal dari dalam agroindustri keripik ubi kayu dan dapat dikendalikan. Faktor internal bisa menjadi kekuatan dan kelemahan dalam keberlangsungan agroindustri keripik ubi kayu.

Adapun faktor-faktor yang menjadi kekuatan adalah sebagai berikut :

\section{a. Cukup tersedia jumlah tenaga kerja}

Pengolahan keripik ubi kayu pada umumnya bisa dikerjakan oleh siapa saja, karena proses produksinya mudah, selain itu di Desa Selamanik banyak sekali penduduk usia produktif sehingga bisa diberdayakan sebagai tenaga kerja pada agroindustri keripik ubi kayu.

b. Produk Tahan Lama

Daya tahan produk keripik ubi kayu tahan lama, sehingga apabila tidak langsung habis keripik masih tetap bisa dikonsumsi.

c. Harga Produk Terjangkau

Harga keripik ubi kayu yang relatif terjangkau oleh semua kalangan menyebabkan pangsa pasar keripik masih luas dan permintaan terus meningkat. d. Produksi Mudah Dilakukan

Proses produksi keripik ubi kayu sangat mudah dan sederhana sehingga dalam pengolahan tidak memerlukan waktu yang lama, dalam jangka waktu satu hari saja bisa memproduksi 5.700 pcs keripik yang siap dipasarkan.

Adapun faktor-faktor yang menjadi kelemahan adalah sebagai berikut :

a. Keterbatasan Permodalan

Sulitnya suatu usaha berkembang disebabkan oleh keterbatasan dalam permodalan, sehingga usaha yang dijalankan tidak bisa terus dikembangkan lebih besar hanya sebatas mengelola modal yang dimiliki seadanya.

b. Kualitas Sumber Daya Manusia yang Kurang

Rendahnya tingkat pendidikan di kalangan masyarakat menyebabkan ketrampilan dan pengetahuan mereka terbatas sehingga dalam pengolahan keripik ubi kayu juga belum bisa menerapkan cara-cara yang modern (pengolahan dengan mesin), masih dengan cara yang sederhana atau manual.

c. Pengemasan Produk Sederhana 
Produk belum menggunakan kemasan yang menarik, Produk yang dihasilkan hanya dikemas dalam plastik berukuran besar kemudian langsung dipasarkan ke pasar dan grosir.

d. Promosi Masih Kurang

Kurangnya promosi menyebabkan produk sulit dikenal ke luar wilayah.

\section{Faktor Eksternal}

Faktor eksternal adalah faktor-faktor di luar agroindustri keripik ubi kayu dan belum dapat dikendalikan sepenuhnya, faktor ekternal tersebut bisa menjadi peluang dan ancaman dalam keberlangsungan agroindustri keripik ubi kayu.

Adapun faktor-faktor yang menjadi peluang adalah sebagai berikut :

\section{a. Pangsa Pasar Masih Luas}

Produk keripik ubi kayu merupakan produk yang banyak diminati oleh masyarakat, sehingga pangsa pasar keripik ubi kayu masih luas, ditambah lagi harga keripik ubi kayu yang relatif terjangkau.

b.

Permintaan Meningkat

Meningkatnya permintaan keripik ubi kayu menyebabkan perajin hampir kewalahan menutupi semua permintaan pelanggan.

c. Tidak dipengaruhi Cuaca dan Iklim

Proses produksi keripik ubi kayu tidak tergantung terhadap cuaca, proses produksi bisa tetap dilakukan dalam kondisi cuaca yang cerah atau hujan.
Adapun faktor-faktor yang menjadi ancaman adalah sebagai berikut :

a.

Kelangkaan bahan Baku

Kelangkaan bahan baku disebabkan saat ini banyak petani ubi kayu yang mengalami gagal panen.

b. Fluktuasi Harga Bahan Baku

Kelangkaan ubi kayu menyebabkan harga tidak menentu.

c. Kurang Adanya Peran dari Pemerintah

Kurangnya peran dari pemerintah sehingga tidak adanya informasi yang sampai ke perajin, baik informasi dalam hal pengajuan bantuan, informasi harga, promosi dan pemasaran.

d. Kenaikan Harga Sarana Produksi

Harga sarana produksi hampir tiap hari mengalami kenaikan, sarana produksi yang sangat berpengaruh yaitu minyak goreng, harga minyak goreng terus melonjak.

\section{Alternatif Strategi}

Penentuan alternatif strategi ditentukan dengan menggunakan matrik SWOT. Rangkuti (2009) menjelaskan bahwa Matrik SWOT dapat menggambarkan secara jelas bagaimana peluang dan ancaman eksternal yang dihadapi perusahaan dapat disesuaikan dengan kekuatan dan kelemahan yang dimilikinya. Matrik ini dapat menghasilkan empat set kemungkinan alternatif strategis, sebagaimana dapat dilihat pada Tabel 2.

\begin{tabular}{|c|c|c|}
\hline IFAS & STRENGHTS $(S)$ & WEAKNESSES $(W)$ \\
\hline & $\begin{array}{l}\text { - Tesedia Cukup Jumlah Tenaga Kerja } \\
\text { - Produk tahan lama } \\
\text { - Harga terjangkau } \\
\text { - Produksi mudah dilakukan }\end{array}$ & $\begin{array}{l}\text { - Permodalan terbatas } \\
\text { - Kualitas SDM kurang } \\
\text { - Pengemasan produk sederhana } \\
\text { - Promosi masih kurang }\end{array}$ \\
\hline OPPORTUNITIES (O) & STRATEGI S-O & STRATEGI W-O \\
\hline $\begin{array}{l}\text { - Tidak ada pesaing produk sejenis di satu } \\
\text { daerah } \\
\text { - Pangsa pasar luas } \\
\text { - Permintaan meningkat } \\
\text { - Tidak dipengaruhi cuaca dan iklim }\end{array}$ & $\begin{array}{l}\text { - Mempertahankan kualitas produksi } \\
\text { dan pengembangan pasar } \\
\text { - Mempertahankan kontinyuitas } \\
\text { produksi untuk memenuhi permintaan }\end{array}$ & $\begin{array}{l}\text { - Optimalisasi kualitas SDM untuk } \\
\text { memenuhi permintaan produk } \\
\text { - Diversifikasi produk untuk } \\
\text { memenuhi pangsa pasar. }\end{array}$ \\
\hline TREATHS $(T)$ & STRATEGI S-T & STRATEGI W-T \\
\hline $\begin{array}{l}\text { - Kelangkaan bahan baku } \\
\text { - Fluktuasi harga bahan baku } \\
\text { - Kurang adanya peran pemerintah } \\
\text { - Kenaikan harga sarana produksi }\end{array}$ & $\begin{array}{l}\text { - Pengelolaan tenaga kerja dan } \\
\text { ketersediaan bahan baku } \\
\text { - Keseragaman harga jual dengan } \\
\text { peran serta pengawasan pemerintah }\end{array}$ & $\begin{array}{l}\text { - } \quad \text { Penganekaragaman pengemasan } \\
\text { untuk memaksimalkan produksi. } \\
\text { - Menjalin kerja sama dengan } \\
\text { pihak terkait dalam menyikapi } \\
\text { permodalan }\end{array}$ \\
\hline
\end{tabular}




\section{MIMBAR AGRIBISNIS \\ ISSN 2460-432.}

Volume 1 - Nomor 3 Juli 2016

\section{KESIMPULAN DAN SARAN \\ Kesimpulan}

Berdasarkan hasil penelitian dan pembahasan dapat diambil kesimpulan sebagai berikut :

1. Biaya total yang dikeluarkan oleh pengusaha keripik ubi kayu selama satu kali proses produksi sebesar Rp 1.152.500,00 penerimaan selama satu kali proses poduksi sebesar $\mathrm{Rp} 2.850 .000,00$ dan pendapatan selama satu kali proses produksi sebesar Rp 1.697.500,00

2. Faktor-faktor internal dan eksternal pada pengembangan agroindustri keripik ubi kayu di Desa Selamanik, Kecamatan Cipaku Kabupaten Ciamis antara lain :

\section{a) Kekuatan}

Faktor-faktor yang menjadi kekuatan dalam pengembangan agroindustri keripik ubi kayu yaitu tersedianya cukup jumlah tenaga kerja, produksi mudah dilakukan, produk keripik ubi kayu yang tahan lama, harga produk yang terjangkau.

b) Kelemahan

Faktor-faktor yang menjadi kelemahan dalam pengembangan agroindustri keripik ubi kayu yaitu permodalan terbatas, kualitas SDM yang masih kurang, pengemasan produk masih sederhana, dan promosi masih kurang.

c) Peluang

Faktor-faktor yang menjadi peluang dalam pengembangan agroindustri keripik ubi kayu yaitu tidak ada pesaing produk sejenis disatu daerah, pangsa pasar yang masih luas, permintaan semakin meningkat, cuaca tidak mempengaruhi produksi.

d) Ancaman

Faktor-faktor yang menjadi ancaman dalam pengembangan agroindustri keripik ubi kayu yaitu kelangkaan bahan baku, fluktuasi harga bahan baku, kurang adanya peran dari pemerintah, dan kenaikan harga sarana produksi.
3. Alternatif strategi yang dapat diterapkan dalam pengembangan agroindustri keripik ubi kayu di Desa Selamanik Kecamtan Cipaku Kabupaten Ciamis.

a. Mempertahankan kualitas produksi dan pengembangan pasar.

b. Mempertahankan kontinyuitas produksi untuk memenuhi permintaan

c. Optimalisasi kualitas SDM untuk memenuhi permintaan produk

d. Diversifikasi produk untuk memenuhi pangsa pasar.

e. Pengelolaan tenaga kerja dan ketersediaan bahan baku.

f. Keseragaman harga jual dengan peran serta pengawasan pemerintah.

g. Penganekaragaman pengemasan untuk memaksimalkan produksi.

h. Menjalin kerja sama dengan pihak terkait dalam menyikapi permodalan.

\section{Saran}

Saran yang dapat diberikan untuk upaya pengembangan agroindustri keripik ubi kayu di Desa Selamanik Kecamatan Cipaku Kabupaten Ciamis adalah sebagai berikut:

1) Penentuan standar kualitas produk keripik ubi kayu dan bahan baku agar dapat memenuhi permintaan konsumen. Produk tidak memiliki daya saing dan menjadi sumber penghasilan utama karena usaha ini mempunyai prospek yang baik.

2) Sebaiknya pengembangan pasar dilakukan dengan meningkatkan promosi dan dengan membuka pangsa pasar baru untuk mendapatkan pelanggan baru, terutama pelanggan di luar kota.

3) Ketersediaan suplai bahan baku ubi kayu sebaiknya lebih terjamin, melalui koordinasi dengan pihak terkait, antara lain petani ubi kayu, pemasok, pemerintah dan pengusaha sendiri. Hal tersebut untuk meminimalisir terjadinya fluktuasi harga bahan baku ubi kayu . Selain dari Kecamatan Cipaku bahan baku diperoleh dari daerah lain agar permintaan produk keripik ubi kayu dapat tetap terpenuhi. 


\section{DAFTAR PUSTAKA}

Aji, B.P. 2012. Strategi Pengembangan Agroindustri Keripik Ubi kayu di Kecamatan Tawangmangu Kabupaten Karanganyar. Skripsi Fakultas Pertanian. Universitas Sebelas Maret. Surakarta.

Anjayani dan Haryanto. 2009. Geografi SMA $X I$. Penerbit Cempaka Putih. Jakarta.

Arikunto, S. 2006. Prosedur Penelitian Suatu Pendekatan Praktek. Rineka Cipta. Jakarta.

Azhari, D.H,. 2004. Dukungan Pengolahan dan Pemasaran Hasil terhadap Pengembangan Agribisnis Hortikultura. Makalah Disampaikan pada Pertemuan Sinkronisasi Pelaksanaan Pengembangan - Hortikultura 2004. Cisarua Bogor, 24 27 Mei 2004.Bogor

David, F.R, 2004. Manajemen Strategi Terjemahan. PT Indeks Kelompok Gramedia. Jakarta

Desa Selamanik. 2015. Monografi Desa Selamanik. Cipaku. Ciamis

Dinas Pertanian Tanaman Pangan Kabupaten Ciamis, 2015. Data Agroindustri Keripik di Kabupaten Ciamis. Ciamis

Hartono. 2007. Geografi: Jelajah Bumi dan Alam Semesta. Citra Praya. Bandung.

Hayati, Maryani dan Manalu. 2004. Pengetahuan Sosial Geografi SMP. ESIS. Jakarta.

Kuntarsih, 2012. Pedoman Penanganan Pascapanen Ubi kayu. Kementerian Pertanian Indonesia. Jakarta.

Kusnandar, T. Mardikanto dan A. Wibowo, 2010. Manajemen Agroindustri, Kajian Teori dan Model Kelembagaan Agroindustri Skala Kecil Pedesaan.Cetakan 1. UNS Press. Surakarta.

Mantra, Ida, Bagus. 2004. Pengantar Studi Demografi. PT Penebar Swadaya. Jakarta.

Nazir M, 2011. Metode Penelitian. Ghalia Indonesia. Bogor.

Pearce, A. J. and Robinson B. R. 2008. Manajemen Strategis Edisi 10. Salemba Empat. Jakarta.

Rangkuti, F, 2009. Analisis SWOT Teknik Membedah Kasus Bisnis. Gramedia
Pustaka Utama. Jakarta.

Sailah. 2005. Teknologi Pertanian. Penebar Swadaya. Jakarta.

Soekartawi, 2001. Pengantar Agroindustri. PT.

Raja Grafindo Persada. Jakarta ,2006. Analisis Usahatani.

Universitas Indonesia. Jakarta.

Suratiyah, K. 2006. Ilmu Usahatani. Penebar Swadaya. Jakarta. . 2009. Ilmu Usahatani. Penebar Swadaya. Jakarta.

Wirosuharjo, Kartomo. 2004. Dasar-dasar Demografi. Universitas Indonesia. Jakarta 


\section{A MIMBAR \\ AgribISNIS \\ ISSN 2460-432}

Volume $1 \bullet$ Nomor $3 \bullet$ Juli 2016

Halaman | 260 